\title{
Constituents of Moquinia kingii
}

\author{
Elisandra Cristina Schinor ${ }^{1 *}$, Diones Aparecida Dias ${ }^{1,2}$ \\ ${ }^{1}$ Departamento de Química, Faculdade de Filosofia, Ciências e Letras de Ribeirão Preto, Universidade de São \\ Paulo, ${ }^{2}$ Departamento de Física e Química, Faculdade de Ciências Farmacêuticas de Ribeirão Preto, \\ Universidade de São Paulo
}

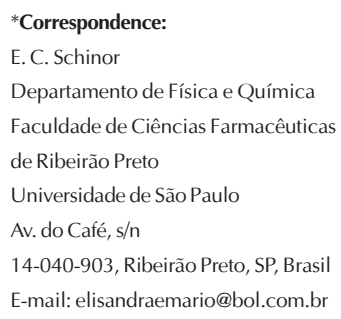

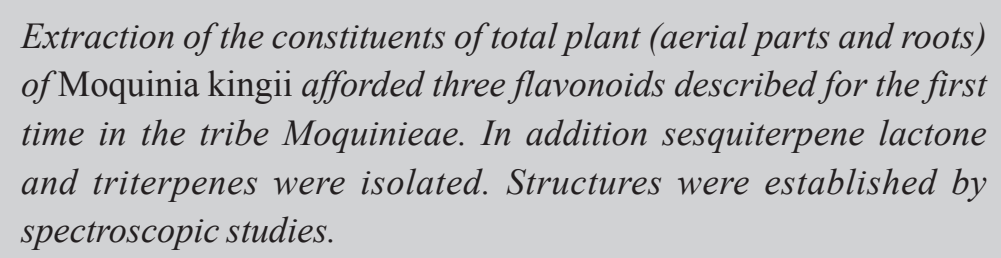
of Moquinia kingii afforded three flavonoids described for the first time in the tribe Moquinieae. In addition sesquiterpene lactone and triterpenes were isolated. Structures were established by spectroscopic studies.

\section{Uniterms}

- Moquinia kingii

- Asteraceae

- Sesquiterpene lactone

- Flavonoids

\section{INTRODUCTION}

The tribe Moquinieae is endemic to Brazil and its species are distributed in Minas Gerais, Espírito Santo and Bahia states and comprises two genera, Pseudostifftia and Moquinia (Robinson, 1999). Both are monotypic genera and Moquinia is represented by Moquinia racemosa, whereas Pseudostifftia by Pseudostiffitia kingii, synonymy Moquinia kingii.

In 1990, Gamerro described Pseudostifftia $\mathrm{H}$. Robinson as synonymy of Moquinia. Thus this genus comprises now two species and in addition, there is a new combination Moquinia kingii (H. Robinson) Gamerro.

Bremer (1994) described two species for Moquinia, in accordance to Gamerro (1990) in the tribe Vernonieae. In the same year, Robinson presented a new tribe Moquinieae based in studies of the spinose pollen and the comparatively short and unsclerified apical anther appendage. Thus, the description in the Vernonieae of Pseudostifftia from Brazil was followed by the addition of the related Moquinia DC and then by the transfer of both genera to the new tribe Moquinieae (Robinson, 1999).

Acetylenes and triterpenes (Bohlmann et al., 1980), guaianolides (Bohlmann et al., 1982), and diol acyclic sesquiterpene (Bohlmann, Jakupovic, 1990) have been detected in the species Pseudostifftia kingii.

Tripanocidal and antimicrobial activities of the crude extract, cynaropicrin and apigenin from $M$. kingii, were previously reported by Schinor et al. (2004), showing significant activity against the trypomastigote forms of Trypanosoma cruzi, as well as against the gram-positive bacteria and yeast strains.

In this work, the main compound isolated from $M$. kingii was cynaropicrin, the same sesquiterpene lactone (guaianolide) obtained from P. kingii, by Bohlmann et al. (1982). In addition, apigenin, luteolin, quercetin, lupeol and lupeol acetate were also isolated of the crude extracts. Flavonoids have been described for the first time in this tribe.

\section{MATERIAL AND METHODS}

\section{Plant material}

The species Moquinia kingii was collected by Walter Vichnewski in Pico das Almas (Bahia) in April 1996 and identified by Prof. Dr. João Semir (Departamento de Botânica, Universidade de Campinas, SP) and a voucher specimen (UEC 35137) was deposited at the Herbarium of this University.

\section{General experimental procedures}

${ }^{1} \mathrm{H}$ and ${ }^{13} \mathrm{C}$ NMR spectra were recorded in Bruker Avance-DRX spectrometer operating a frequency of 
$400 \mathrm{MHz}$ and $100 \mathrm{MHz}$, respectively. TLC were carried out on silica gel plates (Merck) $\mathrm{GF}_{254}$ and Hex/EtOAc 8:2, Hex/EtOAc 3:7, EtOAc/MeOH 7:3 for triterpenes, sesquiterpene lactone and flavonoids, respectively. All compounds were visualized using $\mathrm{H}_{2} \mathrm{SO}_{4}$ followed by heating. Column Chromatography was performed on a normal silica gel 60 (Merck) using hexane, ethyl acetate, methanol and mixture of these solvents as eluents. Gas chromatographic analysis was performed in a HewlettPackard model 5890 Series II Gas Chromatograph with a split injector (split ratio $1: 60$ ) at $260{ }^{\circ} \mathrm{C}$. The detector temperature was $330{ }^{\circ} \mathrm{C}$. The injected volume was $2 \mathrm{~mL}$. Hydrogen was employed as carrier gas at an average linear velocity of $44 \mathrm{~cm} / \mathrm{s}(\mathrm{HP}-50)$ and $42 \mathrm{~cm} / \mathrm{s}$ (HP-1). The HP-50 (cross-linked 50\% phenyl-methylsilicone, $30 \mathrm{~m} \times 0.25 \mathrm{~mm} \times 0.25 \mathrm{~mm}$ ) and HP-1 (crosslinked methyl-silicone, $30 \mathrm{~m} \times 0.25 \mathrm{~mm} \times 0.25 \mathrm{~mm}$ ) capillary columns were employed. For HP-50 the column temperature was $280^{\circ} \mathrm{C}$ (isotherm) and for HP-1 the column temperature program was $250^{\circ} \mathrm{C}$ held for $12 \mathrm{~min}$, increased at $6{ }^{\circ} \mathrm{C} / \mathrm{min}$ to $280{ }^{\circ} \mathrm{C}$, and held this temperature for $30 \mathrm{~min}$. Data were processed on a Hewlett-Packard model 3395 injector. Standard triterpenes: authentic tritepenes isolated from different plant material in our laboratory were used as standard. Cholesterol was used as internal standard.

\section{Extraction and isolation}

Dried and pulverized aerial parts of M.kingii $(2.1 \mathrm{~kg})$ were exhaustively extracted with chloroform and ethanol, successively, at room temperature. The solvents used in each extraction were evaporated under reduced pressure and the crude chloroform extract ( $80.42 \mathrm{~g}$ ) was suspended in $\mathrm{MeOH}-\mathrm{H}_{2} \mathrm{O}$ 9:1 and partitioned with hexane and chloroform.

The chloroformic fraction (18.50 g) was chromatographed on silica gel 60 column chromatography and twenty-three fractions were collected. All fractions were monitored by TLC and purified by preparative TLC and recrystallization. The chloroformic fraction yielded: $60 \mathrm{mg}$ of apigenin (1), $22 \mathrm{mg}$ of lupeol (2), $15 \mathrm{mg}$ of lupeol acetate (3) and $70 \mathrm{mg}$ of cynaropicrin (4).

The crude EtOH extract (40.65 g) was partitioned with dichloromethane and methanol and after evaporation of the solvent under reduced pressure, the dichloromethane fraction $(8.01 \mathrm{~g})$ was fractionated on silica gel 60 column chromatography, yielding $38 \mathrm{mg}$ of apigenin (1), $90 \mathrm{mg}$ of luteolin (5) and $30 \mathrm{mg}$ of quercetin (6).

\section{RESULTS AND DISCUSSION}

Compounds 1, 5 and $\mathbf{6}$ were identified by comparison of spectral data with the reported values (Mabry et al., 1970). Compounds $\mathbf{2}$ and $\mathbf{3}$ were identified by HRGC and co-injection with authentic standard. The guaianolide 4 (Figure 1) was identified by comparison ${ }^{1} \mathrm{H}$ NMR spectral data with reported values in literature (Bohlmann et al., 1982). HMQC and ${ }^{1} \mathrm{H}-{ }^{1} \mathrm{H}$ COSY spectral data (Tables I and II) were determined and reported for the first time.

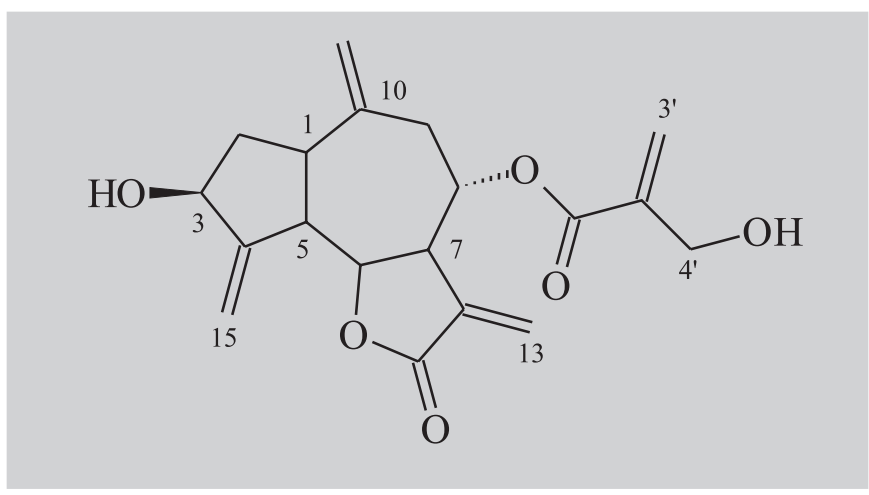

FIGURE 1 - Chemical structure of the compound 4.

The triterpenes $\mathbf{2}$ and $\mathbf{3}$, of natural occurrence in many plants, mainly in Asteraceae, have shown several biological activities. Lupeol has been demonstrated antitumoral, antioxidant, cytotoxic and diuretic (Noldin el al., 2003) activities. Compounds 1, 5 and 6, are characterized mainly as antioxidants and this activity for quercetin has been comparable to the potent food antioxidant TBHQ (Arora et al., 1998).

Cynaropicrin $\mathbf{4}$ is found in many species of Asteraceae. The sesquiterpene lactones are usually characterized by a $\alpha$-methylene- $\gamma$-lactone group, which may react with sulphydryl group of proteins by a Michael addition (Milbrodt et al., 1997). The reaction between these groups could be responsible for the toxic of effect sesquiterpene lactones (Noldin et al., 2003). This compound showed $89 \%$ lysis against trypomastigote forms of $T$. cruzi in concentration of up to $100 \mathrm{mg} / \mathrm{mL}$ and inhibited the growth of gram-positive bacteria and yeast strains (Schinor et al., 2004).

Cynaropicrin was the main compound isolated from $M$. kingii, and it is the same sesquiterpene lactone, guaianolide, obtained from Pseudostiffitia kingii, by Bohlmann (1982). Thus both species, $M$. kingii and $P$. kingii can be synonymous, although $P$. kingii has presented other sesquiterpene lactones not found yet in M. kingii, maybe because the plants were collected in different habitat 
TABLE I - ${ }^{1} \mathrm{H}-\mathrm{NMR}$ spectral data for $4\left(400 \mathrm{MHz}, \mathrm{CDCl}_{3}\right)$

\begin{tabular}{|c|c|c|c|c|}
\hline $\mathrm{H}$ & $\delta(\mathrm{ppm})$ & $\mathrm{M}$ & $\mathrm{J}(\mathrm{Hz})$ & Correlated with $\mathrm{H}$ \\
\hline 1 & 2.98 & $\overline{d d}$ & $11.5 ; 8.6$ & $2 \alpha, 2 \beta$ \\
\hline $2 \mathrm{a}$ & 1.72 & ddd & $11.5 ; 12.5 ; 7.1$ & $1,2 \beta, 3$ \\
\hline $2 b$ & 2.17 & ddd & $8.6 ; 12.5 ; 11.8$ & $1,2 \alpha, 3$ \\
\hline 3 & 4.53 & dddd & $11.8 ; 7.1 ; 1.7 ; 2.0$ & $2 \alpha, 2 \beta, 15 \alpha, 15 \beta$ \\
\hline 5 & 2.85 & ddl & $10.6 ; 1.5$ & $6,15 \alpha, 15 \beta$ \\
\hline 6 & 4.30 & dd & $10.6 ; 9.5$ & 5,7 \\
\hline 7 & 3.24 & dddd & $9.5 ; 9.5 ; 3.0 ; 2.5$ & 6,8 \\
\hline 8 & 5.13 & ddd & $9.5 ; 5.0 ; 3.5$ & $7,9 \alpha, 9 \beta$ \\
\hline $9 a$ & 2.71 & $\mathrm{dd}$ & $5.0 ; 14.8$ & $8,9 \beta$ \\
\hline $9 b$ & 2.40 & dd & $3.5 ; 14.8$ & $8,9 \alpha$ \\
\hline $13 a$ & 6.20 & $\mathrm{dd}$ & 3.0 & $7,13 \beta$ \\
\hline $13 b$ & 5.66 & $\mathrm{dd}$ & 2.5 & $7,13 \alpha$ \\
\hline $14 \mathrm{a}$ & 5.46 & $\mathrm{~d}$ & 1.2 & $14 \alpha$ \\
\hline $14 \mathrm{~b}$ & 5.36 & $\mathrm{~d}$ & 1.2 & $14 \beta$ \\
\hline $15 \mathrm{a}$ & 5.15 & ddd & $1.7 ; 1.5$ & $3,5,15 \beta$ \\
\hline $15 b$ & 4.93 & ddd & $2.0 ; 1.5$ & $3,5,15 \alpha$ \\
\hline 3'a & 6.35 & $\mathrm{dd}$ & $3.0 ; 1.2$ & $4^{\prime}, 3^{\prime} \beta$ \\
\hline 3 'b & 6.00 & $\mathrm{dd}$ & $3.0 ; 1.5$ & $4^{\prime}, 3^{\prime} \alpha$ \\
\hline $4^{\prime}$ & 4.35 & $\mathrm{~d}$ & 1.2 & $3^{\prime} \alpha$ \\
\hline
\end{tabular}

TABLE II - ${ }^{13} \mathrm{C}-\mathrm{NMR}$ spectral data for $4(75 \mathrm{MHz}$, $\left.\mathrm{CDCl}_{3}\right)^{\mathrm{a}}$

\begin{tabular}{lll}
\hline $\mathbf{H}$ & $\boldsymbol{\delta}(\mathbf{p p m})$ & HMQC \\
\hline 1 & $44.9(d)$ & 1 \\
2 & $38.5(t)$ & $2 \alpha, 2 \beta$ \\
3 & $72.8(d)$ & 3 \\
4 & $151.7(s)$ & - \\
5 & $50.9(d)$ & 5 \\
6 & $78.6(d)$ & 6 \\
7 & $47.2(d)$ & 7 \\
8 & $74.0(d)$ & 8 \\
9 & $36.4(t)$ & $9 \alpha, 9 \beta$ \\
10 & $141.6(s)$ & - \\
11 & $137.2(s)$ & - \\
12 & $169.6(s)$ & - \\
13 & $122.6(t)$ & $13 \alpha, 13 \beta$ \\
14 & $117.8(t)$ & $14 \alpha, 14 \beta$ \\
15 & $112.9(t)$ & $15 \alpha, 15 \beta$ \\
1 & $165.4(q)$ & - \\
2 & $139.5(q)$ & - \\
3 & $125.8(t)$ & $3 ' \alpha, 3$ ' $\beta$ \\
4 & $60.7(d)$ & 4 \\
\hline
\end{tabular}

a - multiplicities were determinate with assistance of DEPT $135^{\circ}$ experiment. and conditions of environment could interfere in the biosynthesis routes this compound (Spring, 1991).

The compounds $\mathbf{1}, \mathbf{5}$ and $\mathbf{6}$, are found in M. kingii, but there are no any reports for $P$. kingii. Therefore it is necessary more studies to support the synonymy of both genera.

\section{ACKNOWLEDGEMENTS}

We wish to thank Prof. Dr. Walter Vichnewski for plant collected and Prof. Dr. João Semir for plant identification. This work was supported by grants from FAPESP, CAPES and CNPq.

\section{RESUMO}

\section{Constituintes de Moquinia kingii}

A extração da planta total (partes aéreas e raiz) de Moquinia kingii forneceu três flavonóides, descritos pela primeira vez na tribo Moquinieae, além de lactona sesquiterpênica e triterpenos. As estruturas foram determinadas por estudos espectroscópicos.

Unitermos: Moquinia kingii. Asteraceae. Lactona sesquiterpênica. Flavonóides. 


\section{REFERENCES}

ARORA, A.; MURALEEDHARAN, G.; STRASBURG, N.; STRASBURG, M.G. Structure-activity relationships for antioxidant activities of a series of flavonoids in a liposomal system. Free Radi. Biol. Med, v.24, p. 1355$1363,1998$.

BOHLMANN, F.; JAKUPOVIC, J. Progress in the chemistry of the Vernonieae (Compositae). Pl. Syst. Evol. Suppl., v. 4, p. 3-43, 1990.

BOHLMANN, F.; SINGH, P.; KING, R.M.; ROBINSON, H. New guaianolides from Pseudostifftia kingii. Phytochemistry, v. 21, p. 1171-1172, 1982.

BOHLMANN, F.; ZDERO, C.; KING, R.M.; ROBINSON, H. Seven guaianolides from tribe Vernonieae. Phytochemistry, v. 19, p. 2669-2673, 1980.

BREMER, K. Asteraceae, cladistics \& classification. Portland, Oregon, Timber Pres, cap.10, p. 202-233, 1994.

GAMERRO, J.C. Identidad de Pseudostifftia con Moquinia (Compositae) y consideraciones sobre la ubicacion tribal del taxon. Darwiniana, v. 30, p. 123-136, 1990.

MABRY, T.J.; MARKHAM, K.R.; THOMAS, M.B. The systematic identification of flavonoids. Berlin: SpringerVerlag, 1970. p. 354.
MILBRODT, M.; SCHRÖDER, F.; KÖNIG, W.A. 3,4- $\beta$ epoxy-8-deoxycumambrin $\mathrm{B}$, a sesquiterpene lactone from Tanacetum parthenium. Phytochemistry, v. 44, p. 471-474, 1997.

NOLDIN, V.F.; CECHINEL FILHO, V. Composição química e atividades biológicas das folhas de Cynara scolymus I. (Alcachofra) cultivada no, Brasil. Quim. Nova, v. 26, p. 331-334, 2003.

ROBINSON, H. Two new genera of Vernonieae (Asteraceae) from Brazil. Heterocypsela and Pseudostifftia. Phytologia, v. 44, p. 442-450, 1979.

ROBINSON, H. Notes on the tribes Eremonthamneae, Gundelieae and Moquinieae, with comparisons of their pollen. Taxon, v. 43, p. 33-44, 1994

ROBINSON, H. Generic and subtribal classification of American Vernonieae. Washington: Smithsonian Institution Press, 1999.

SCHINOR, E.C., SALVADOR, M.J., ITO, I.Y., DIAS, D.A. Trypanocidal and Antimicrobial Activities of Moquinia kingii, Phytomedicine, v. 11, p. 224-229, 2004.

SPRING, O. Trichome microsampling of sesquiterpene lactones for the use of systematic studies. In: FISCHER, N.H.; ISMAN, M.B.; STAFFORD, H.A. (Eds.). Modern Phytochemical Methods, 1o Ed., New york, Plenum Press, cap. 9, p. 319-345, 1991.

Recebido para publicação em 10 de outubro de 2003. Aceito para publicação em 08 de dezembro de 2004. 